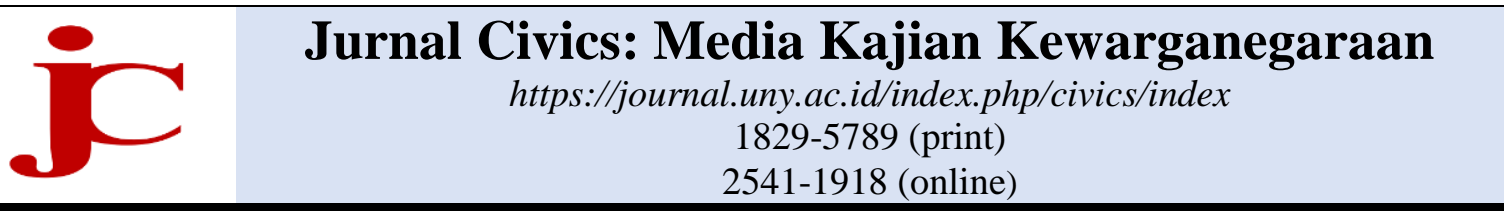

\title{
Penguasaan kompetensi profesional guru oleh mahasiswa peserta praktik pengalaman pembelajaran
}

\author{
Oksiana Jatiningsih a 1, Maya Mustika Kartika Sari b 2 , Siti Maizul Habibah c 3 , Rr. \\ Nanik Setyowati ${ }^{d}$, Muhammad Turhan Yani e 5 , Agus Satmoko Adi ${ }^{\text {f } 6}$ \\ a, b, c, d, e, f Fakultas Ilmu Sosial dan Hukum, Universitas Negeri Surabaya, Surabaya, Indonesia \\ ${ }^{1}$ oksianajatiningsih@unesa.ac.id*; ${ }^{2}$ mayamustika@unesa.ac.id; ${ }^{3}$ sitimaizulhabibah@unesa.ac.id; \\ 4mturhanyani@unesa.ac.id; ${ }^{5}$ rr_nanik_setyowati@yahoo.com; ${ }^{6}$ agussatmoko@unesa.ac.id \\ *korespondensi penulis
}

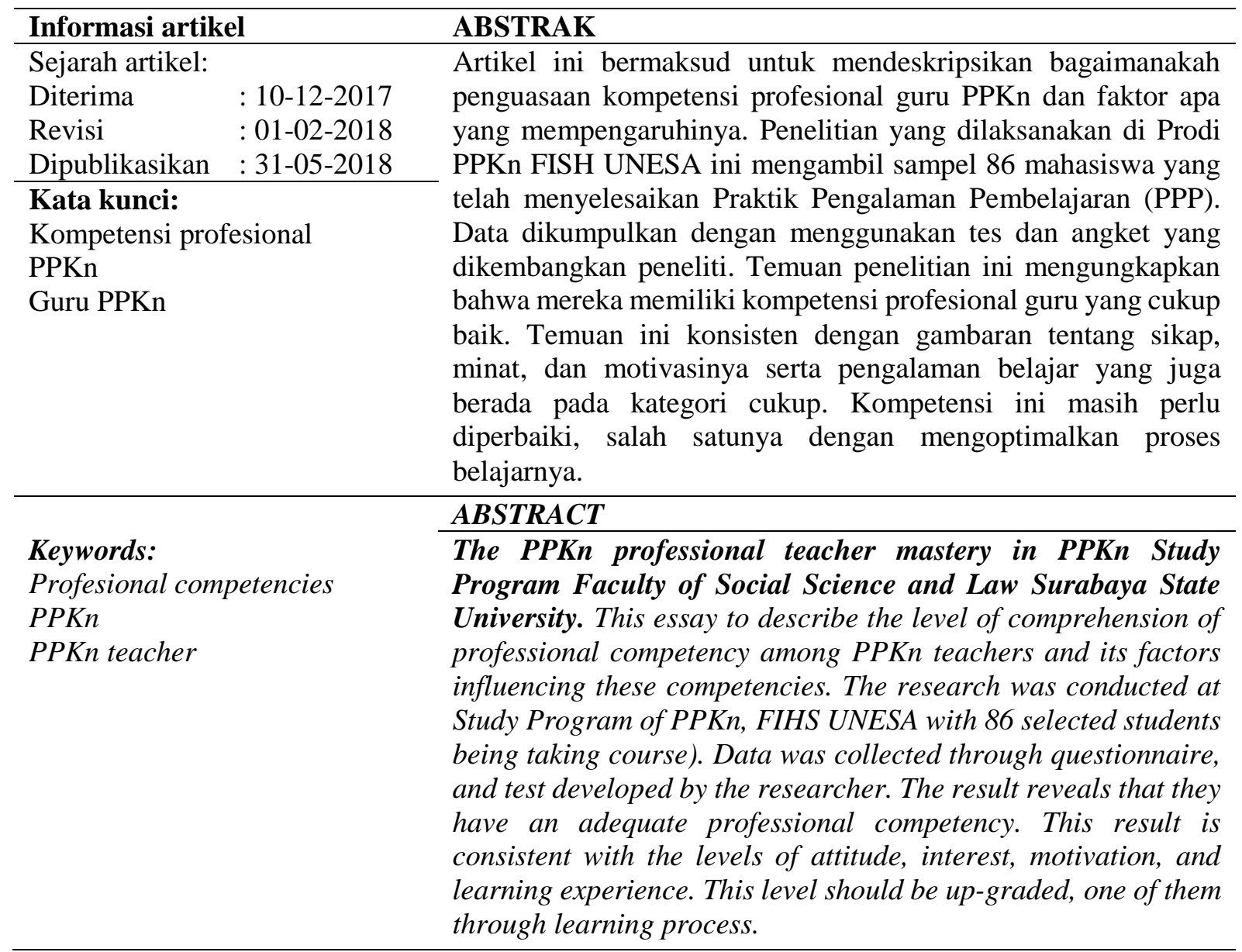

Copyright $(2018$ Oksiana Jatiningsih, dkk

\section{Pendahuluan}

Kompetensi menjadi jaminan keberhasilan seseorang untuk bekerja dengan profesional. Hal ini karena kompetensi menandai adanya kepemilikan pengetahuan, keterampilan, dan kemampuan yang dituntut oleh jabatan seseorang (Djamarah, 1994)). Kompetensi terkait dengan pengetahuan, keterampilan, dan sikap yang relevan dengan profesi dan tindakan tertentu sesuai dengan prinsip etika, standar, panduan, dan nilai-nilai suatu profesi (Rodolfa et al., 2005). Karena itu, kepemilikan kompetensi menggambarkan profesionalisme seseorang dalam bekerja. Dengan kata lain, seseorang disebut" profesional" jika mempunyai kemampuan teoretis dan praktis dalam bidangnya masingmasing. 
Guru yang profesional tentu dituntut untuk memiliki seperangkat kompetensi sebagai seorang guru. Seorang guru profesional memiliki empat kompetensi dasar yaitu kompetensi pedagogis, kepribadian, sosial, dan profesional. Cooper (Christine, 2008) mengemukakan bahwa seorang guru wajib memiliki empat kompetensi yaitu kompetensi pedagogis, kompetensi profesional, kompetensi personal, dan kompetensi kepribadian. Sesuai dengan itu, seorang guru wajib: (1) mempunyai pengetahuan tentang belajar dan tingkah laku manusia; (2) mempunyai pengetahuan dan menguasai bidang ilmu yang dibinanya; (3) mempunyai sikap yang tepat tentang dirinya, sekolah, teman sejawat dan bidang studi yang dibinanya; (4) mempunyai keterampilan teknik mengajar.

Keempat kompetensi tersebut terintegrasi dalam kinerja guru dan merupakan satu kesatuan utuh dalam menggambarkan profesionalisme seorang guru yang terlampir dalam Lampiran Peraturan Menteri Pendidikan Nasional Nomor 16 Tahun 2007. Profesionalisme seorang guru. Penguasaan materi merupakan persoalan penting yang harus dimiliki oleh seorang guru sebagai penanda penguasaan kompetensi profesionalnya. Penguasaan materi dengan baik merupakan bagian dari tuntutan utama dalam kemampuan guru (Ali, 2000). Terkait dengan penguasaan materi, struktur, konsep, dan pola pikir keilmuan, sesuai dengan Peraturan Menteri Pendidikan Nasional Nomor 16 Tahun 2007, maka kompetensi yang harus dimiliki seorang guru PPKn adalah: (1) Memahami materi, struktur, konsep, dan pola pikir keilmuan yang mendukung mata pelajaran Pendidikan Kewarganegaraan. (2) Memahami substansi Pendidikan Kewarganegaraan yang meliputi pengetahuan kewarganegaraan (civic knowledge), nilai dan sikap kewarganegaraan (civic disposition), dan keterampilan kewarganegaraan (civic skills). Menunjukkan manfaat mata pelajaran pendidikan kewarganegaraan. Penguasaan materi ini menandai dimilikinya kecakapan guru dalam memahami, menerapkan, menganalisis/ menyintesiskan, mengevaluasi, dan mengkreasi sesuatu yang relevan dengan materi (materi pokok dan materi penunjang) dalam proses pembelajaran.

Kualitas pendidikan menentukan kualitas lulusannya. Kualitas kemampuan guru berdampak pada kualitas pendidikan dan produk yang dihasilkan. Guru berpengaruh besar pada lingkungan kelas (Egeberg, McConney, \& Price, 2016, p. 8). Konsisten dengan itu, kualitas pendidikan calon guru yang dialami mahasiswa pun akan menentukan pula kualitasnya sebagai calon guru. Oleh karena itu, dalam rngka membangun pendidikan yang berkualitas, penyiapan calon guru dan pembinaan guru memegang peran yang sangat strategis. Terkait dengan itu pendidikan guru sebagai subsistem pendidikan nasional merupakan faktor yang sangat strategis dalam pembangunan pendidikan yang berkualitas. Di sinilah peran penting Lembaga Pendidikan Tenaga Kependidikan (LPTK) bagi masa depan pendidikan. Bahkan dalam rangka menjaga dan meningkatkan kualitas guru, Lembaga Pendidikan Guru (LPG) merupakan salah satu cara untuk mengembangkan kompetensi guru (Hamalik, 2009). LPG atau LPTK berperan penting dalam menentukan kualitas guru.

Penguasaan guru terhadap materi pelajaran Pendidikan Pancasila dan Kewarganegaraan (PPKn) mencakup komponen yang hendak dikembangkan dalam Pendidikan Kewarganegaraan yang terdiri atas pengetahuan kewarganegaraan (civic knowledge) merupakan materi substansi yang harus diketahui oleh warga negara, berkaitan dengan hak dan kewajiban sebagai warga negara dan pengetahuan yang mendasar tentang struktur dan sistem politik, pemerintahan dan sistem sosial yang ideal sebagaimana terdokumentasi dalam Pancasila dan UUD 1945 maupun yang terkonversi dalam kehidupan berbangsa dan bernegara serta nilai-nilai universal dalam masyarakat demokratis serta cara-cara kerja sama untuk mewujudkan kemajuan bersama dan hidup berdampingan secara damai dalam masyarakat internasional. Dengan kata lain, 
secara ideal dan instrumental konsep, visi, dan misi serta muatan PPKn tersebut sudah secara utuh mengintegrasikan filsafat, nilai, dan moral Pancasila dengan keseluruhan tuntutan psiko-pedagogis dan sosial-kultural warga negara dalam konteks pembudayaan Pancasila, UUD NRI 1945, Bhinneka Tunggal Ika, dan NKRI (Winataputra, 2014, p. 5).

PPKn sebagai salah satu mata pelajaran untuk mengembangkan misi pendidikan nasional yakni menjadikan warga negara yang baik, dengan demikian guru PPKn menjadi tulang punggung bagi tercapainya misi tersebut (Suyato, Murdiono, Mulyono, \& Arpannudin, 2016). Salah satu tugas penting seorang guru PPKn adalah membelajarkan demokrasi. Nilai-nilai demokrasi diawali dari kelas yang demokratis (Rohmawati, Triyanto, \& Muchtarom, 2016). Apa yang dilakukan guru PPKn mempengaruhi kualitas peserta didik belajar berdemokrasi. Salah satu peran pendidikan kewarganegaraan saat ini adalah pendidikan demokrasi, yaitu untuk meningkatkan kemampuan partisipasi warganegara dalam kehidupan politik dan berdemokrasi (Winarno, 2013). Begitu pentingnya peran PPKn dan guru PPKn dalam menjaga keberlangsungan bangsa. Karena itu, penting untuk mengkaji apakah calon guru PPKn yang dihasilkan di LPTK UNESA akan dapat mengemban tugas penting itu dilihat dari penguasaannya terhadap materi PPKn sebagai salah satu indikator dari kompetensi profesional guru PPKn.

Dalam rangka penyiapan calon guru yang profesional yang baik, proses dan pengalaman belajar yang dialami oleh mahasiswa calon guru di LPTK menjadi salah satu variabel penting. Situasi pembelajaran yang dialami mahasiswa akan mempengaruhi kualitas penguasaan materinya. Berdasarkan wawancara awal yang dilakukan kepada beberapa mahasiswa yang telah menempuh matakuliah praktik pembelajaran terungkap bahwa persoalan yang paling mengganggunya saat praktik adalah penguasaan materi. Terkait dengan itu, penelitian ini dimaksudkan untuk (1) mendeskripsikan bagaimanakah penguasaan kompetensi profesional guru oleh mahasiswa PPKn; (2) mendeskripsikan faktor-faktor (internal dan eksternal) yang mempengaruhi hal tersebut. Agar tidak terjadi kesalahpahaman terhadap istilah "profesional" maka dalam penelitian ini permasalahan profesional dibatasi pada penguasaan terhadap materi mata pelajaran PPKn.

Melalui penelitian ini bagi lembaga, diharapkan dapat diperoleh informasi tentang kualitas pembelajaran di PPKn yang turut menentukan keberhasilan mahasiswa dalam menguasai kompetensi profesional sebagai guru PPKn. Meskipun selain pengalaman belajar, kompetensi Profesionalisme ini juga dipengaruhi oleh individu itu sendiri. Bagi mahasiswa, penelitian ini dapat memberikan informasi untuk melakukan evaluasi diri tentang kesiapan profesional dirinya sebagai calon guru PPKn serta kelemahan dan kekuatan dirinya tentang kompetensi profesionalnya dalam rangka penyiapan diri sebagai calon guru PPKn.

\section{Metode}

Metode yang digunakan dalam penelitian ini adalah metode deskriptif untuk menggambarkan atau menguraikan hasil penelitian melalui narasi, angka, dan grafik. Subjek dalam penelitian ini adalah mahasiswa PPKn yang telah menempuh matakuliah PPP (Praktik Pengalaman Pembelajaran). Terdapat 90 mahasiswa yang memprogram mata kuliah ini, namun ada 86 mahasiswa yang menjadi sampel dalam penelitian ini, empat orang yang lain sedang tidak masuk kelas ketika dilakukan pengambilan data.

Sesuai dengan rumusan masalah, variabel dalam penelitian ini yaitu: penguasaan kompetensi profesional guru dan faktorfaktor yang mempengaruhi penguasaan kompetensi profesional guru oleh mahasiswa PPKn. Yang dimaksud dengan "penguasaan kompetensi profesional" adalah kualitas pengetahuan mahasiswa PPKn terkait dengan kecakapannya dalam menguasai materi, struktur, konsep, dan pola pikir keilmuan serta pengembangannya yang mendukung mata pelajaran yang diampu. Sedangkan yang 
dimaksud dengan faktor-faktor yang mempengaruhi mahasiswa PPKn dalam menguasai kompetensi profesional guru yaitu unsur-unsur atau elemen-elemen baik yang bersifat internal (sikap dan motivasi terhadap profesi guru) maupun eksternal (proses dan pengalaman pembelajaran) yang mempengaruhi perolehan belajar mahasiswa terkait dengan kecakapannya dalam menguasai materi, struktur, konsep, dan pola pikir keilmuan serta pengembangannya yang mendukung mata pelajaran yang diampu.

Berdasarkan data yang diperoleh dapat dikemukakan bahwa tes baik untuk dipergunakan sebagai instrument penelitian. Sedangkan angket dipergunakan untuk menggali data tentang faktor-faktor yang mempengaruhi penguasaan kompetensi profesional mahasiswa. Ada dua aspek sebagai indikator yaitu aspek internal yang terkait dengan sikap, minat, dan motivasi profesionalisme mahasiswa dan aspek eksternal yang terbagi menjadi pengalaman dan situasi belajar yang dialami mahasiswa. Sebelum dipergunakan angket telah divalidasi oleh ahli. Setelah direvisi dalam beberapa hal Tabel Skor Mahasiswa Materi Kompetensi Profesional Guru PPKn

\begin{tabular}{cccccccccc}
\hline Interval & $\mathbf{X}$ & $\mathbf{f 1}$ & $\mathbf{X f 1}$ & $\mathbf{f 2}$ & $\mathbf{X f 2}$ & $\mathbf{f 3}$ & $\mathbf{X f 3}$ & $\mathbf{f 4}$ & $\mathbf{X f 4}$ \\
\hline $25-30$ & 27 & 0 & 0 & 0 & 0 & 0 & 0 & 0 & 0 \\
$20-24$ & 23 & 4 & 92 & 1 & 23 & 11 & 253 & 20 & 460 \\
$15-19$ & 17 & 30 & 510 & 21 & 357 & 41 & 697 & 43 & 731 \\
$10-14$ & 13 & 43 & 559 & 41 & 533 & 28 & 364 & 21 & 273 \\
$5-9$ & 7 & 9 & 63 & 22 & 154 & 6 & 42 & 2 & 14 \\
$1-4$ & 3 & 0 & 0 & 1 & 3 & 0 & 0 & 0 & 0 \\
Jumlah & & 86 & 1224 & 86 & 1070 & 86 & 1356 & 86 & 1478 \\
Mean & & & 14,23 & & 12,44 & & 15,77 & & 17,19 \\
\hline
\end{tabular}

Berdasarkan data pada tabel di atas, dapat dikemukakan bahwa dari yang paling rendah berturut-turut penguasaan profesional terhadap materi PPKn adalah rumpun hukum, ke-PKn-an, sosial, dan politik. Meskipun tidak ada mahasiswa yang penguasaan kompetensi profesional buruk atau sangat buruk, namun rata-rata penguasaan kompetensi materi kompetensi profesional yang berada pada kategori kurang atau cukup seperti revisi kalimat dan ejaan, maka instrumen dipergunakan untuk menggali data. Data dianalisis secara deskriptif kuantitatif dengan persentase.

Pengambilan data dilakukan pada hari yang telah disepakati bersama mahasiswa yang menjadi subjek penelitian ini. Pengambilan tes dilakukan sekitar satu bulan setelah mereka menyelesaikan praktik mengajar di sekolah (Matakuliah Program Pengalaman Pembelajaran-PPP). Moment pengambilan tes ini telah diinformasikan dua minggu sebelumnya, sehingga diasumsikan mereka telah menyiapkan diri dengan baik sebelum tes dilaksanakan.

\section{Hasil dan Pembahasan}

Penguasaan mahasiswa terhadap materi kompetensi profesional guru PPKn dilihat dari empat aspek materi dalam PPKn (kePKn-an. Hukum, Sosial, dan Politik) dituangkan dalam soal maka data yang diperoleh melalui tes tersebut diperoleh data sebagaimana disajikan pada tabel di bawah ini baik saja tentu bukan hal yang menggembirakan. Karena hal ini akan menyangkut kualitasnya sebagai seorang guru ketika ia mengajar. Diharapkan penguasaan kompetensi profesional ini berada pada kategori sangat baik, atau setidaknya baik. Fakta bahwa hasil tes tersebut ternyata menunjukkan posisi penguasaan yang cukup baik dan kurang baik sepatutnya menjadi perhatian dari lembaga. 
Ada dua faktor yang dapat mempengaruhi penguasaan kompetensi profesional guru, yaitu faktor internal dan eksternal. Faktor internal yaitu faktor-faktor yang terdapat pada diri orang yang bersangkutan itu sendiri seperti: latar belakang pendidikan, pengalaman mengajar, pelatihan, penataran, dan etos kerja. Etos kerja seseorang sangat dipengaruhi oleh sikapnya terhadap profesinya. Keyakinan seorang guru mengenai profesi yang diembannya, dan memberikan dasar kepada guru untuk membuat respons atau perilaku sesuai dengan pilihannya. Sikap guru terhadap profesi juga mempengaruhi tindakan guru dalam menjalankan profesinya. Jika seorang guru memiliki sikap positif terhadap profesinya, maka guru tersebut akan menjalankan fungsi dan perannya dengan baik. Demikian pula sebaliknya, jika seorang guru memiliki sikap negatif terhadap profesinya, maka guru tersebut akan menjalankan fungsi dan perannya tidak sesuai dengan tuntutan profesi yang diembannya.

Faktor eksternal yaitu faktor-faktor yang terdapat dari luar individu, seperti sikap terhadap objek yang dijadikan sasaran subjek; kewibawaan orang yang mengemukakan suatu sikap; sifat orang-orang atau kelompok yang mendukung sifat tersebut; dan situasi pada saat sifat dibentuk. Faktor eksternal yang mempengaruhi kompetensi guru, misalnya iklim kerja, kebijakan organisasi, lingkungan sosial kerja, sarana dan prasarana. Bagi mahasiswa calon guru, faktor eksternal tersebut juga mencakup pengalaman dan proses belajar yang dialami selama mereka menjadi mahasiswa.

Dalam penelitian ini, faktor yang mempengaruhi penguasaan kompetensi profesional mahasiswa dibedakan menjadi dua, yaitu aspek internal yang terkait dengan sikap, minat, dan motivasi kompetensi profesional mahasiswa dan aspek eksternal yang terbagi menjadi pengalaman dan situasi belajar yang dialami mahasiswa.

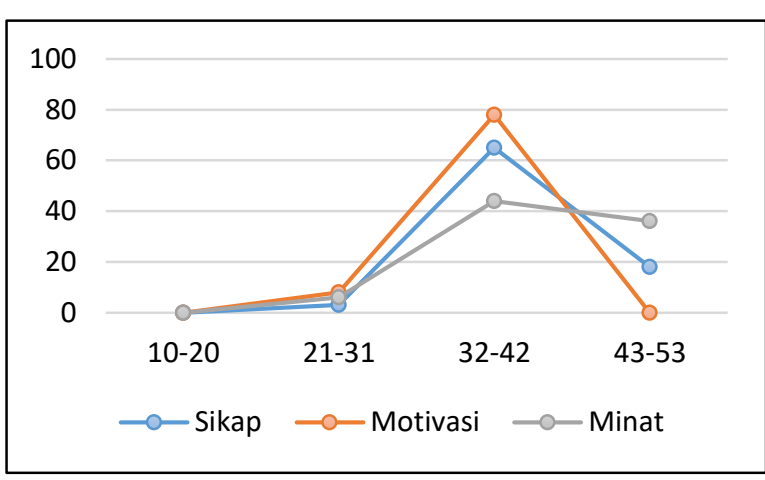

Grafik 1. Aspek Internal Faktor yang Mempengaruhi Sikap Kompetensi Profesional Mahasiswa Calon Guru

Berdasarkan kriteria sebagaimana termuat di atas dikemukakan bahwa sebagian besar mahasiswa memiliki sikap kompetensi profesional internal dalam kategori cukup baik. Tentu saja diharapkan hal ini berada pada kategori baik, sehingga hal ini bisa menjadi daya dorong bagi mahasiswa untuk makin menguatkan upayanya dalam menguasai kompetensi profesional guru.

Sebagian besar mahasiswa memiliki sikap, motivasi, dan minat kompetensi profesional cukup baik, bahkan jika dicermati beberapa di antaranya memiliki modalitas internal yang baik terkait dengan sikap dan motivasi kompetensi profesional nya. Sikap, minat, dan motivasi ini menjadi daya dorong dalam diri individu mahasiswa untuk mencapai kompetensi profesional (guru). Dengan demikian dapat dikatakan bahwa tidak terdapat hambatan dari diri mereka dalam meraih keberhasilan kompetensi profesional nya. kurang berhasilnya mahasiswa calon guru sangat mungkin tidak bersumber pada sikap kompetensi profesional nya, tetapi disebabkan oleh variabel lain, misalnya kecerdasan mereka. Selain itu, penjelasan lebih lanjut mengapa mahasiswa tidak memiliki pengetahuan kompetensi profesional yang maksimal (baik atau sangat baik) mungkin karena faktor eksternal, yaitu pengalaman belajar mahasiswa dan situasi pembelajaran yang terjadi di PPKn. Pengalaman dan situasi belajar yang dialami mahasiswa calon guru akan berdampak pada perolehan belajar mahasiswa dalam menguasai kompetensi profesionalnya. 


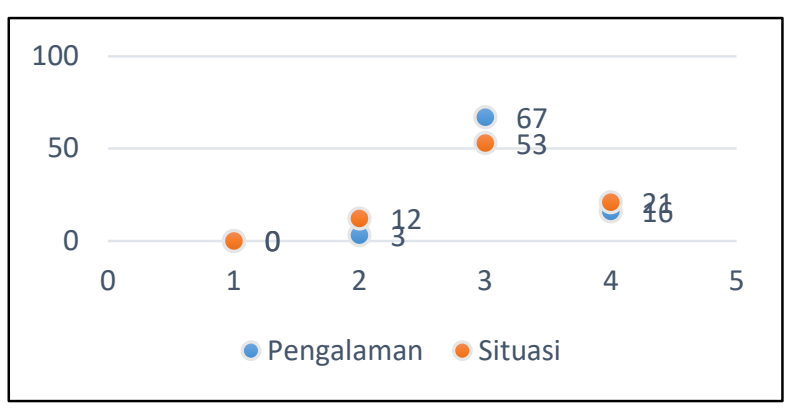

Grafik 2. Aspek Eksternal yang Mempengaruhi Penguasaan Kompetensi Profesional Mahasiswa.

Berdasarkan data pada grafik 2 dapat dicermati bahwa menurut mahasiswa pengalaman belajar dan situasi pembelajaran di PPKn berada di posisi yang kondusif untuk mengantarkan mereka menguasai materi kompetensi profesional. Sebagian besar mereka memandang bahwa proses tersebut cukup baik, bahkan baik, dan tidak seorang pun yang menyatakan rendah/buruk. Berdasarkan data yang ada rerata penilaian mereka terhadap situasi pembelajaran yang terjadi sebesar 39 untuk pengalaman belajar dan 38 untuk situasi belajar yang mereka alami. Dengan demikian dapat dikatakan bahwa kedua hal ini menunjukkan bahwa aspek eksternal yang terkait dengan faktor yang mempengaruhi pembelajaran berada pada posisi cukup baik.

Kompetensi profesional merupakan salah satu unsur yang harus dimiliki oleh guru yaitu dengan cara menguasai materi pembelajaran secara luas dan mendalam. Dalam penelitian ini terungkap bahwa penguasaan pengetahuan profesionalisme PPKn dan proses pembelajaran serta sikap, motivasi dan minat mahasiswa terhadap profesi keguruan berjalan seiring. Semuanya berada pada kategori cukup. Padahal mestinya penting bagi guru untuk memiliki penguasaan materi dengan baik. Oleh karena itu hal ini dapat menjadi perhatian Prodi PPKn. Dalam konteks membentuk warga negara demokratis, maka guru harus memiliki kemampuan membentuk warga negara yang demokratis, yaitu: (1) elaborasi pemahaman akan nilai- nilai demokrasi dan keberagaman (refleksi dan sensitivitas moral); (2) kapasitas (efikasi internal dan eksternal); (3) hubunganhubungan aktif (komitmen dan koneksi); (4) kemauan transformasi (bersifat terbuka terhadap kritik ); dan (5) kemampuan berdialog ( empati dan kompetensi dialogis) (De Groot, 2011).

Memang pada umumnya kualitas mahasiswa baru yang masuk ke pada Prodi PPKn bukanlah mahasiswa kelas satu (terbaik). Tidak jarang mereka meletakkan PPKn sebagai pilihan setelah bidang studi yang lain gagal dimasukinya. Raw input yang kurang baik akan dapat berubah menjadi baik ketika proses belajar memiliki daya dorong yang kuat untuk menumbuhkan motivasi perubahan pada diri mahasiswa. Oleh karena itu mengoptimalkan proses belajar agar lebih baik menjadi kebutuhan utama di Prodi PPKn.

Pembentukan sikap profesionalisme guru dilakukan melalui proses belajar yang panjang. Pembentukan sikap keguruan ini dapat terjadi melalui pengalaman berulangulang. Mahasiswa calon guru yang telah menempuh, memahami dan mengembangkan mata kuliah keguruan baik teoretis maupun praktik, pada dirinya akan tumbuh motivasi untuk menumbuhkan dan mengembangkan sikap keguruan yang merupakan proses terbentuknya sikap keguruan. Menjadi guru adalah panggilan jiwa yang menjadi guru profesional ditunjukkan dengan tanggungjawabnya dalam melaksanakan seluruh pengabdiannya secara profesional, dan kemampuannya memikul dan melaksanakan tanggung sebagai guru kepada peserta didik, orang tua, masyarakat, bangsa negara, dan agamanya.(Samad, 2013).

Sikap keguruan adalah pengetahuan, keterampilan, perilaku atau etika mahasiswa yang mencerminkan kepribadian guru profesional yang mengarah pada kompetensi kepribadian dan kompetensi sosial. Terbentuknya sikap keguruan mahasiswa dapat dilihat dan diukur melalui pengetahuan tentang sikap keguruan, kesadaran untuk membentuk sikap keguruan dan kemampuan mengembangkan diri serta tanggung jawab terhadap tugas.

Guru yang profesional pada dasarnya memiliki motivasi intrinsik sebagai pendorong untuk mengembangkan diri ke arah perwujudan kompetensi profesional. 
Guru yang memiliki motivasi untuk melakukan pekerjaan, menunjukkan adanya dorongan dalam dirinya untuk bekerja dengan baik. Jika seorang guru mempunyai harapan yang besar dapat berprestasi tinggi, dan jika ia menduga bahwa dengan tercapainya prestasi yang tinggi ia akan merasakan akibat-akibat yang ia harapkan, maka ia akan mempunyai motivasi yang tinggi untuk bertindak professional pula.

Seorang guru profesional adalah pribadipribadi unggul terpilih (Mulyana, 2010). Sebaliknya, jika guru merasa yakin tidak akan dapat mencapai prestasi kerja, maka ia akan kurang termotivasi untuk menjadi profesional. Demikian juga yang terjadi pada mahasiswa calon guru. Meningkatnya sikap, minat, dan motivasi profesional akan berdampak pada lebih banyak usaha dan prestasi yang lebih baik dalam menguasai kompetensi profesional. Data lain tentang kualitas input mahasiswa program studi kependidikan yang tidak termasuk kategori unggulan, mungkin saja menjadi hambatan pencapaian kompetensi profesional. Tetapi hal ini sekaligus menjadi tantangan untuk dapat menjadikan mereka menjadi output yang berkualitas. Dalam konteks inilah, pembelajaran sebagai faktor eksternal yang turut mempengaruhi pencapaian kompetensi profesional guru begitu penting diperhatikan. Jika pengalaman dan situasi pembelajaran yang optimal dalam meningkatkan sikap, minat, dan motivasi mahasiswa calon guru, serta kemampuan intelektualnya, maka dapat diprediksi bahwa kompetensi profesional pun akan meningkat. Temuan dari penelitian Kedzior (2004), mengenai kompetensi profesional guru dipengaruhi oleh salah satunya faktor "content-focused". Beberapa penelitian menunjukkan bahwa keterampilan dan pemahaman guru terkait langsung dengan tingkat pengalaman pengembangan profesional yang fokus pada konten materi pelajaran (Desimone, Porter, Garet, Yoon, \& Birman, 2002). Artinya penguasaan materi merupakan hal yang esensial bagi penguasaan kompetensi profesional calon guru dan guru. Pengembangan kompetensi profesional ini tidak hanya berhenti ketika menyelesaikan pendidikan keguruan saja, namun harus terus diperbaharui setiap saat. Selanjutnya ketika seorang calon guru telah menjadi guru di sekolah, pengembangan profesionalisme guru dapa dilakukan dengan berapa model pengembangan profesionalisme guru dapat dilakukan dengan (1) mentoring (Kedzior, 2004), (2) Content-Based Collaborative Inquiry/Cognitively Guided Instruction (Musyawarah Guru Mata Pelajaran/MGMP) yang menjadi wahana untuk pengembangan materi ajar dan strategi pengajaran (Franke, Carpenter, Levi, \& Fennema, 2001), dan (3) lesson study, untuk melihat satu sama lain dan mendiskusikan kelebihan dan kekurangan yang tampak sehingga dapat meningkatkan keterampilan instruksionalnya (Kedzior, 2004).

\section{Simpulan}

Penguasaan kompetensi profesional mahasiswa calon guru terhadap materi PPKn berada pada kategori cukup baik. Demikian pula dengan faktor-faktor yang menurut mahasiswa terjadi dalam proses pembelajaran. Secara internal mahasiswa memiliki modalitas yang cukup baik, demikian pula dengan faktor eksternal yang terjadi di PPKn. Hal ini menunjukkan bahwa prestasi belajar dalam hal ini penguasaan materi kompetensi profesional PPKn bukanlah variabel tunggal. Keberhasilannya ditentukan oleh dua aspek utama yaitu aspek internal dan eksternal dari mahasiswa yang bersangkutan. Baik mahasiswa maupun Prodi PPKn dapat belajar bahwa peningkatan kualitas diri dalam belajar dan melayani mahasiswa masih perlu diperhatikan. Prodi PPKn perlu melakukan evaluasi dan penguatan proses pembelajaran yang bermakna terutama terkait dengan penguasaan materi kompetensi profesional yang paling rendah, yaitu materi Ke-PKn-an dan Hukum. Hasil penelitian ini dapat menjadi bahan refleksi diri; dapat menilai potensi dirinya dan bersaing dalam menembus dunia kerja, misalnya ketika salah satu kriteria itu adalah penguasaan materi kompetensi profesional guru PPKn. 


\section{Ucapan Terima Kasih}

Terima kasih penulis haturkan kepada para Dekan Fakultas Ilmu Sosial dan Hukum Universitas Negeri Surabaya yang telah memberikan bantuan dana penelitian dalam penelitian ini.

\section{Referensi}

Ali, H. M. (2000). Guru dalam proses belajar mengajar. Bandung: PT Sinar Baru Algensindo.

Christine, M. (2008). Perilaku organisasi. Jakarta: Ghalia Indonesia.

De Groot, I. (2011). Why we are not democratic yet: The complexity of developing a democratic attitude. In W. Veugelers (Ed.), Education and humanism: Linking autonomy and humanity (pp. 79-94). Roterdam, Boston, Taipe: Springer Science \& Business Media.

Desimone, L. M., Porter, A. C., Garet, M. S., Yoon, K. S., \& Birman, B. F. (2002). Effects of professional development on teachers' instruction: Results from a three-year longitudinal study. Educational Evaluation and Policy Analysis, 24(2), 81-112.

Djamarah. (1994). Pengertian kompetensi dan profesi keguruan. Gorontalo: Ideal Publishing.

Egeberg, H., McConney, A., \& Price, A. (2016). Classroom management and national professional standards for teachers: A review of the literature on theory and practice. Australian Journal of Teacher Education, 41(7), $1-18$.

https://doi.org/10.14221/ajte.2016v41 n7.1

Franke, M. L., Carpenter, T. P., Levi, L., \& Fennema, E. (2001). Capturing teachers' generative change: a followup study of professional development in Mathematics. American Educational Research Journal, 38(3), 653-689.
Hamalik, O. (2009). Pendidikan guru berdasarkan pendekatan Kompetensi. Jakarta: Bumi Aksara.

Kedzior, M. (2004). Teacher professional development. University of Delaware Education Research \& Development Center, 4552.

Mulyana, E. H. (2010). Guru berkualitas: Profesional dan cerdas emosi. Jurnal Saung Guru, 1(2), 1-11.

Rodolfa, E., Eisman, E., Rehm, L., Bent, R., Nelson, P., \& Ritchie, P. (2005). A cube model for competency development: Implications for psychology educators and regulators. Professional Psychology: Research and Practice, 36(4), 347-354. https://doi.org/10.1037/0735-

7028.36.4.347

Rohmawati, R., Triyanto, \& Muchtarom, M. (2016). Kompetensi pedagogik guru Pendidikan Kewarganegaraan dalam membangun kecerdasan berdemokrasi warga negara. PKn Progresif, 11(1), 298-311.

Samad, D. (2013). Guru: ideologi dan profesi. Al-Ta'Lim, 20(2), 357-362. https://doi.org/10.15548/jt.v20i2.32

Suyato, Murdiono, M., Mulyono, B., \& Arpannudin, I. (2016). Upaya pembentukan warga negara yang baik dan tantangan yang dihadapi oleh para guru PKn peserta SM3T 2015. Jurnal Civics: Media Kajian Kewarganegaraan, 13(2), 137-150. https://doi.org/10.21831/civics.v13i2. 12737

Winarno. (2013). Pembelajaran pendidikan kewarganegaraan. Isi, strategi dan penilaian. Jakarta: PT. Bumi Aksara.

Winataputra, U. S. (2014). Diskursus aktual tentang paradigma pendidikan kewarganegaraan dalam konteks kurikulum 2013. In Seminar Nasional AP3KNI (pp. 1-12). Surakarta: AP3KNI dan Universitas Negeri Sebelas Maret. 